\title{
Mastery of Functional Anatomy and meaningful learning in introductory Biomechanics
}

\section{O domínio da anatomia funcional e a aprendizagem significativa em um curso introdutório de biomecânica}

\author{
${ }^{1}$ Rachel Saraiva Belmont rachelsbelmont@gmail.com \\ 2 Duane Knudson \\ ${ }^{3}$ Paula Hentschel Lobo da Costa \\ ${ }^{4}$ Evelyse dos Santos Lemos
}

\begin{abstract}
Although there is a consensus that musculoskeletal anatomy is essential knowledge for learning biomechanical concepts, there are few studies that have documented the nature of this interdependence. A qualitative case study approach was used to identify how the applied knowledge of functional anatomy might influence meaningful learning of biomechanics. Thirteen physical education students enrolled in an introductory biomechanics course at a university, in Rio de Janeiro, Brazil, participated in this study. Meaningful learning theory was the major theoretical framework used in the study and content analysis of students' learning activities were performed. Findings suggest that these students' prior knowledge of functional anatomy was insufficient, fragmented, or missing, and these weaknesses in prerequisite knowledge and their approach to learning can be barriers to meaningful learning of biomechanical concepts.
\end{abstract}

Keywords: constructivism; prior knowledge; physical education; science education.

\section{RESUMO}

Embora exista um consenso que a anatomia musculoesquelética seja conhecimento essencial para a aprendizagem da Biomecânica, poucos estudos têm enfatizado a natureza dessa interdependência. A presente investigação, um estudo de caso com abordagem qualitativa, teve como objetivo identificar como o conhecimento sobre Anatomia Funcional pode influenciar na aprendizagem significativa da Biomecânica. Treze estudantes de Educação Física, matriculados na disciplina Biomecânica em uma universidade do Rio de Janeiro, Brasil, foram os participantes da investigação. A Teoria da Aprendizagem Significativa foi o principal referencial teórico e os registros foram categorizados por meio da Análise de Conteúdo, conforme a natureza dos mesmos. Os resultados sugerem que os conhecimentos prévios sobre Anatomia Funcional deste grupo de estudantes, diagnosticados como insuficientes e/ou fragmentados e/ou ausentes, podem dificultar a aprendizagem significativa de conceitos biomecânicos.

Palavras-chave: construtivismo; conhecimento prévio; educação física; educação em ciências.

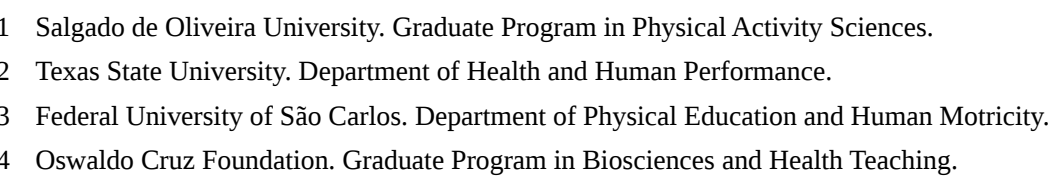




\section{INTRODUCTION}

Biomechanics is an interdisciplinary field that has been defined as "[...] the study of the structure and function of biological systems by means of the methods of mechanics” (HATZE, 1974, p. 189). As learning biomechanics demands the development of linkages between concepts of physics and biology, undergraduate students usually consider it difficult to understand. Studies of student learning using standardized tests of biomechanical concepts report low levels of improvement, similar to studies of mechanical concepts in introductory physics (KNUDSON, 2006; KNUDSON et al., 2003).

Biomechanics is regarded as a core course for physical education teacher preparation programs. While national organizations and university faculties consider biomechanical knowledge essential to help physical educators perform their professional duties, nonetheless it is rather easy to verify that these professionals seldom use their knowledge of biomechanics as a basis for their professional practice.

The weak and inconsistent use of biomechanical knowledge by physical education professionals seems multifactorial, but one influential factor is inadequate teaching and learning strategies in the introductory biomechanics courses (BELMONT, 2010). Functional anatomy is a prerequisite course for most undergraduate biomechanics courses in physical education programs (GARCEAU; KNUDSON; EBBEN, 2011), however, many biomechanics faculties feel that this prerequisite knowledge is either missing, fragmented, or incorrect in many of their students (BARLOW, 1997). Anatomy can be defined, according to Knudson (2007, p. 65), as “[...] the descriptive study of the structure of the human body". Knudson (2007) noted that this anatomical knowledge stands as an important prerequisite for the study of movement and that it should be linked to biomechanical concepts in order to determine how human movement is created.

The poor prior knowledge in functional musculoskeletal anatomy is a common observation of biomechanics faculties (BARLOW, 1997; GARCEAU; KNUDSON; EBBEN, 2011). Despite this, few researchers have emphasized the relation between students' anatomy prior knowledge and meaningful learning of biomechanical concepts and principles. In physical education teacher training, Rezende, Garcia and Cola (2006) proposed a resource that could help students to connect anatomical and mechanical contents. Studies in medical sciences also have emphasized new teaching methods in anatomy education (BRENTON et al, 2007; GINNS; FRASER, 2010; KALMEY; KULESZA, 2013; POKHREL; BHATNAGAR, 2013; TERRELL, 2006).

Besides the relevance of strategies and instructional resources to students learning, introductory biomechanics planning also must consider students' prior knowledge and their main difficulties in the learning process. Considering this, the purpose of this study was identify how the applied knowledge of functional anatomy might influence students' meaningful learning of biomechanics.

\section{MEANINGFUL LEARNING THEORY}

Meaningful learning theory could pose one explanation for how poor mastery of biomechanical concepts might be related to poor mastery of functional anatomical concepts. Meaningful learning results from a process in which an individual associates, in a non-arbitrary (non-randomly) and substantive (non-literal) way, new information to the relevant ideas that already exist in the individual's cognitive structure (AUSUBEL; NOVAK; HANESIAN, 1978; AUSUBEL 2000). Essentially, it is a process of assimilation of new concepts in which both the new knowledge and the student's preexisting knowledge are modified. According to this constructivist learning theory, Ausubel, Novak and Hanesian (1978, p. iv) hypothesize that “[...] the most important relevant single factor influencing learning is what the learner already knows [...]" and, thus, prior knowledge is crucial for the occurrence of a new meaningful learning. 
Meaningful learning theory may also explain the poor application of biomechanical concepts by students and physical education teachers. Ausubel (2000) postulates that the opposite approach to meaningful learning is mechanical or rote learning that occurs when new knowledge is arbitrarily linked to the learner's cognitive structure (it seldom establishes a linkage to specific prior knowledge). Ausubel also hypothesizes that rote learning creates little or no acquisition of new meanings, the frailty of the new concepts, with limited used in novel situations. It is possible that many biomechanics students and physical education teachers poor application of anatomy and biomechanics is related to the adoption of a rote learning strategy. Such context is different from the one in which the individual meaningfully constructs his/her own meanings and is likely more capable of applying them to novel situations.

Two conditions are requisite for implementation of meaningful learning experiences: teaching materials must be potentially meaningful to the students and the students must be willing to learn in a meaningful way (AUSUBEL, 2000). This means that these materials, besides having the potentiality for the establishment of relations among new meanings and those the student already has, the students must intentionally relate such knowledge in non-arbitrary way. The result of such interaction is novel knowledge (concept and/or proposition) with a personal or idiosyncratic meaning.

This theory can help biomechanics instructors to understand how students can learn with greater personal meaning and consider essential course planning variables such as students' prior knowledge and their difficulties in comprehending the relationship between concepts.

\section{METHODS}

One introductory biomechanics course within a physical education degree at one university of Rio de Janeiro, Brazil was selected to implement a qualitative case study (LÜDKE; ANDRÉ, 2013) on student's understanding of functional anatomy and its application to biomechanics. This required course was offered in the fourth term, with sixty-hours on instruction distributed along two 1 hour and 40 minutes weekly meetings. A total of 13 students (five women and eight men) enrolled in this course gave informed consent to participate in the study. These volunteers varied from 19 to 25 years of age. These students concluded two anatomy terms before starting biomechanics class, one just focused on musculo-skeletal and another on general human anatomical systems. Both anatomy classes were taught using theoretical and practice strategies that will not be explored in this study. The biomechanics professor had responsibility over all decisions concerning the course, while the primary author integrated this study into the course as the teaching assistant.

Data collection occurred through participant observation complemented by a semi-structured interview with the students, and by copies of written activities performed by the students. Study records included field notes, transcriptions of audio recordings of all the classes and interviews, as well as the students' answers in the final exam.

Our focus was the knowledge that students expressed in their speech, attitudes, and behaviors along these classes, mostly (a) in the difficulties they have explicitly and/or inexplicitly conveyed, (b) their general knowledge of joint movements, muscle actions, types of contractions, and, lastly, and (c) their study habits.

Meaningful learning theory was the major theoretical framework and these records were analyzed with content analysis (BARDIN, 2009). We considered the frequency of elements of interest, and the presence or lack of elements whenever they were relevant to our research analysis. Students were identified by random numbers from one to thirteen, preceded by the letter "S" representing each student, as both teachers have been referred to as $\mathrm{T} 1$ and $\mathrm{T} 2$. 


\section{$4 \quad$ RESULTS AND DISCUSSION}

The analysis of students' speech and interactions in the course showed their doubts about basic functional anatomy concepts in class discussions, course activities, and readings. Many students presented difficulties in identifying joint movements and muscle groups, and the types of muscle group contractions. Such doubts permeated all classes and were manifested more explicitly in five of the thirty classes sessions, including later sessions focusing on application of biomechanics. For instance, in lesson 27, four groups of students worked on movement analysis problems. The students had previously developed and recorded their own movement on video. In one of the groups, student S1 (demonstrating the movement) discussed with S9 and S12 whether a given wrist movement corresponded to extension or flexion and, without coming to any conclusion, asked to T1:

S1: Is this movement here wrist extension or wrist flexion? (performing such movement).

T1: Please, ask S4.

S4: It is flexion (with conviction).

S1: I hope you are right. (not convinced yet).

Some minutes later S3 and S13, in a different discussion context, expressed similar doubts:

S3 and S13: Teacher, are the pronation and supination movements of hand with elbow at $90^{\circ}$ performed in the shoulder?

T2: What performs pronation and supination?

S3: I believe everything does.

S13: No way!

T2: The shoulder performs internal and external rotation. This here is different than that there (teacher demonstrates performing movements of internal and external rotation of the shoulder with a flexed elbow).

S13: Ok, but this movement from there to here is a rotation (student demonstrates by performing forearm supination together with the hand).

S3 and S13: But this movement here is an external rotation.

T2: External rotation of whom?

S13: Inaudible sounds.

T2: This movement here is not performed by the shoulder, but in the radioulnar joint.

These dialogs are representative of several others that explicitly demonstrate the students' difficulties in identifying joint movements and the muscle actions that produced them. In the first example, S1 knew that the wrist allowed both the flexion and extension movements, though the student had doubts concerning the meaning of these terms. S3 and S13 believed that movements of forearm and hand pronation and supination were performed by the shoulder joint. This type of mistake can result from not paying enough attention or from not being aware of the relations between distal and proximal muscular insertions. Such doubts show that, even before hardships with integrating biological and mechanical concepts, these students, though they have had a passing grade in anatomy and are mostly through biomechanics, have not completely learned the most general ideas about the nature of some basic movements, such as flexion, extension, and of medial and lateral rotation.

We now turn to assessing our students' success and learning through analysis of their answers to a question proposed on the last class test. Considering our purpose we were focusing on the item, shown in Figure 1, that question: "What muscle groups are working in each stage of the represented movement and what types of contraction are they performing?” The question still oriented the students to consider just lower limbs in their answers. Other movements were examined in previous lessons, so this question was based on a novel movement to be consistent with the theory of meaningful learning (AUSUBEL, 2000). 
Figure 1 - Sequence of a single leg squat exercise used as an exam question to evaluate students' understanding of functional anatomical analysis of a novel movement. The movement was split into four phases (P1-P4). The drawing was made by the subject instructor

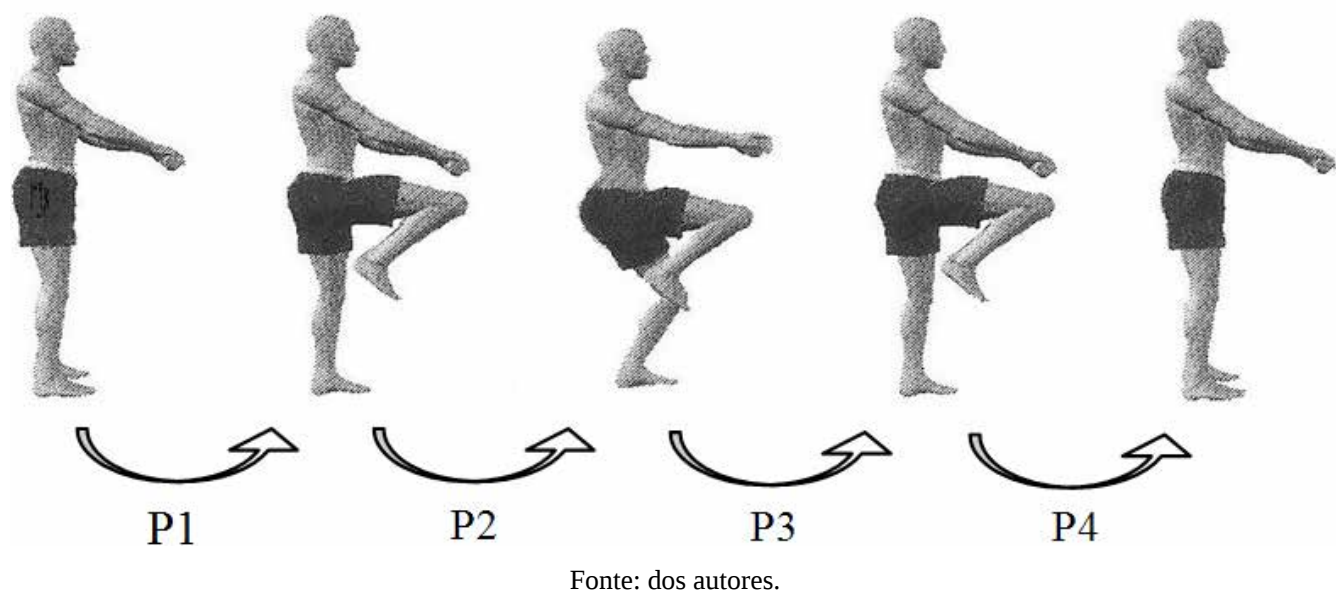

Correct responses require that the movement was organized around distinct phases (P1 to P4) created between the distinct positions illustrated. Actions of muscle groups must be logically inferred from functional anatomical analysis of the positions relative to the gravitational torques created at the lower extremity joints. In other words, students should consider the relation between gravity, joint axes, and segmental masses that were taught during classes. Hence, we took as correct just the answers shown in Table 1.

Table 1 - Expected answers to the question described in the text and Figure 1

\begin{tabular}{|c|c|c|c|}
\hline Phase & Lower Limb & Muscle group & Contraction Type \\
\hline \multirow{3}{*}{ P1 } & \multirow{3}{*}{ Right } & Hip flexors & Concentric \\
\hline & & Knee flexors & Concentric \\
\hline & & Ankle flexors & Concentric/ Isometric \\
\hline \multirow{6}{*}{ P2 } & \multirow{3}{*}{ Right } & Hip flexors & Isometric \\
\hline & & Knee flexors & Isometric \\
\hline & & Ankle flexors & Isometric \\
\hline & \multirow{3}{*}{ Left } & Hip extensors & Eccentric \\
\hline & & Knee extensors & Eccentric \\
\hline & & Ankle extensors & Eccentric \\
\hline \multirow{6}{*}{ P3 } & \multirow{3}{*}{ Right } & Hip flexors & Isometric \\
\hline & & Knee flexors & Isometric \\
\hline & & Ankle flexors & Isometric \\
\hline & \multirow{3}{*}{ Left } & Hip flexors & Concentric \\
\hline & & Knee flexors & Concentric \\
\hline & & Ankle flexors & Concentric \\
\hline \multirow{3}{*}{ P4 } & \multirow{3}{*}{ Right } & Hip flexors & Eccentric \\
\hline & & Knee flexors & Eccentric \\
\hline & & Ankle flexors & Eccentric/ Isometric \\
\hline
\end{tabular}


Ideally, all students should have considered in each phase the three lower extremity joints in the sagittal plane directly involved in the movement. However, only the student S9 submitted a complete analysis mentioning all joints in each phase (Table 2).

As we were interested on the nature of knowledge and how it influenced their interpretation of biomechanical concepts and phenomena, the individual analyses of the students' answers allow us to identify that, among the mentioned joints, not a single student had attained the total number of correct contractions in phase four, unlike students S11, S10, S7 and S12 that scored zero, two, four and four correct answers respectively. Figure 2 illustrates the error distribution of students' answers for hip and knee actions. The students' responses for the muscles and actions at the ankle joint were tabulated just if they had chosen to mention them. Besides the incorrect answers, we have computed as an error the absence of any mention of hip and/or knee joints.

Table 2 - Distribution of students' responses relative to hip, knee, and ankle axes of rotation in all phases

\begin{tabular}{cccc}
\hline Phases/joints & Hip & Knee & Ankle \\
\hline In all & S1, S4, S6, S9, S13 & S1, S3, S4, S5, A6, S8, S9, S13 & S3, S9 \\
In at least one & S2, S3, S7, S8, S10, S11, S12 & S2, S10, S11, S12 & S1, S2, S8, S10, S12, S13 \\
In absence & S5 & S7 & S4, S5, S6, S7, S11 \\
\hline
\end{tabular}

Fonte: dos autores.

We have not intended to only quantify errors but to understand their nature, which has a close linkage to functional anatomy knowledge and its relation with the biomechanics learning process. So as to get a general diagnostic of the group of students concerning such knowledge, we quantified 364 possibilities of errors and their nature distributed across four phases (Figure 3). The total of all students' responses resulted in 186 errors (51\%) from a perfect score. Figure 3 shows the main concentration of errors found in phases 2, 3, and mostly in 4. Unlike the expected answers presented in Table 1, for some students the movement of the non-support limb in P1 was performed by hip extensors (S7, S10 and S11) and knee extensors (S12). In phase 2, errors were concentrated on the left lower limb, since for the majority of students the hip flexors (S2, S4, S9 and S12), knee flexors (S2, S4, S8, S9, S11 and S12), and ankle flexors (S2, S3, S8, S9 and S12) were responsible for movement. In phase P3 difficulties resided again in the left lower limb including remarks of hip flexors (S10, S11 and S12) and ankle flexors (S3, S10 and S12). In phase P4, we observed the higher percentage of inadequate answers by the students, which indicated as muscle groups accountable for movements as the hip extensors (S1, S2, S4, S7, S8, S9, S11 and S13), knee extensors (S1, S2, S4, S8, S9, S10, S12 and S13) and, lastly, the ankle extensors (S9).

Figure 2 - Total of errors comparing with total possibility of right answers per student in response to question

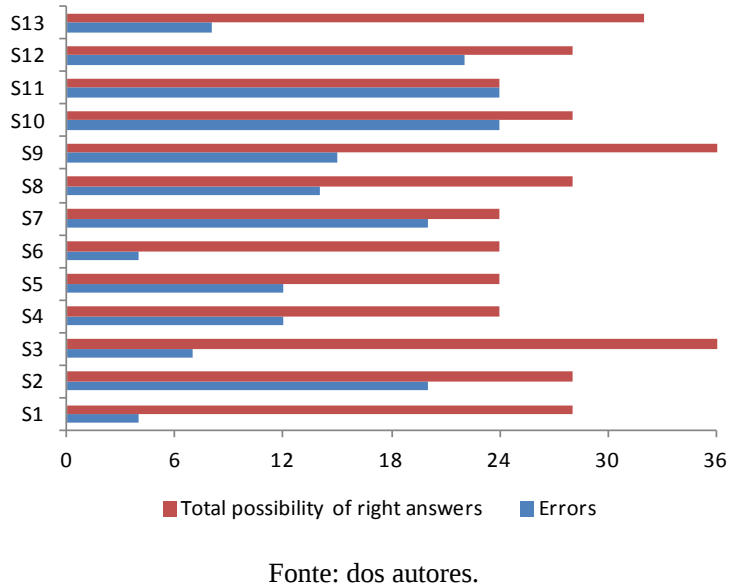


Problems related to the identification of types of muscle contraction (concentric, eccentric, and isometric) became evident in the four phases durations, not only when the muscle groups were not accurate, but also when they were correct. Furthermore, difficulty in recognizing eccentric contractions in the movement was evident. In phases 1, 2 and 3, the most common errors were due to the absence of joints considered essential to the movement (Figure 1).

Figure 3 - Distribution of student errors across the four phases (P1-P4) of the squat movement in the exam question

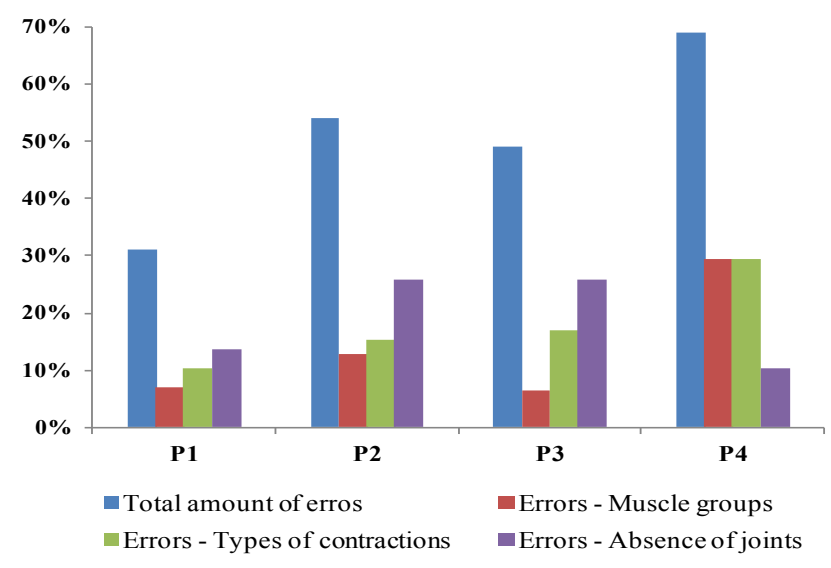

Fonte: dos autores.

Although the relation between students' anatomy knowledge and learning biomechanical concepts is hypothesized by biomechanics faculty and apparent in this study, we could find no published research to compare to our findings. In a physical education context Rezende, Garcia and Cola (2006) did not discuss about the essence of students' problems in learning biomechanics, but proposed a hypermedia system to help students make relations among mechanics and anatomy concepts. They found that the system could help students to have an interdisciplinary vision about human movement and improve their attitudes to learn biomechanics. They also documented small changes in learning through students' concept maps.

Most studies in anatomy and biomechanics education seems to focus on teaching methods and students' perceptions about them. Researches in biomedical sciences have focused teaching strategies and instructional resources that can help students to improve their learning in anatomy. Different proposals on the use of multimedia (BRENTON et al., 2007; POKHREL; BHATNAGAR, 2013), instructional design based on educational psychology (TERRELL, 2006), personalization of paper-based instructional materials (GINNS; FRASER, 2010) and implementation of proactive intervention examination (KALMEY; KULESZA, 2013) have been studied. Besides these, students' opinion and perceptions about anatomy curriculum, teaching methodology and assessment techniques (NAGAR et al., 2012), strategies used to learn the content (PANDEY; ZIMITAT, 2007) and attitudes towards teaching and learning in a multiprofessional context (MITCHELL; MCCRORIE; SEDGWICK, 2004) were also investigated.

In keeping with meaningful learning theory, learning is a complex process which relies on the learner's willingness to relate substantively and non-arbitrarily the new knowledge to his/her prior knowledge. It was, therefore, necessary to understand student study habits because it can influence how they deal with the new information. Their answers from individual interviews reinforced the idea that the problem does not dwell only in the nature of knowledge and the teaching process. The majority of these students focused on rote memorization and consider studying as means to getting a passing grade on tests. Most of students stated that while they were in high school they had only studied on the eve of major tests. However, when they were asked to compare the time they invested in studying, at college and high school levels, nine students said they were studying more at college level while just one said his study habits were "the same" as in high school, and the other three stated that they were studying "less" now. Concerning to the frequency of study for the biomechanics course, one student 
reported that he studied almost everyday, while five expressed that they reviewed the content once a week, and the other seven replied they only studied on the eve of tests.

In several instances, even in informal conversation with the researcher outside the classroom, the students' preoccupation with a verbatim reproduction of the definitions of concepts presented in class by the teacher and/or textbooks was evident. This conception of learning as rote learning may be a result of the usually constructed way use during elementary and high school. In concordance with this, studies that focused on students' perceptions in anatomy education elements found that memorization is commonly used as strategy to learning (BERGMAN et al., 2013; MILLER et al., 2002; SMITH; MATHIAS, 2010).

Rote learning can be an obstacle to meaningful learning, because instead of encouraging a student to relate, substantively and non-arbitrarily, the new ideas to the ones he/she already has, the student will rather invest time and effort to memorize not construct knowledge. Lemos (2005) notes that memorizing is far from being an easy task. This practice, which targets assessments that require the mere reproduction of the textbook and/or of the teacher's narration, induces the student to invest in actions that contribute little to long-term knowledge formation and application.

These results are consistent with the warning of Ausubel, Novak and Hanesian (1978) about the necessity to consider both conditions for meaningful learning: the nature of student knowledge and intentionality for meaningful learning. That is, even when the material is potentially meaningful, a student can use memorization rather than a meaningful learning strategy linking new knowledge and previous knowledge. In this case, as commonly happens in all education levels, students will not be successful in meaningful learning and long-term mastery of concepts.

When we think about the character of meaningful learning, it may not reasonable to expect students to have a consolidated, stable and deep knowledge on these subjects after a single term of instruction in functional musculoskeletal anatomy and in biomechanical concepts. The expectation was that these students could have made some relations among more general concepts from anatomy and mechanics to understand and explain the movement in question and its causes, but this was not the case in the majority of these students.

In the case of physical education, whose professional practice is centered on human movement, academic courses and faculty have to handle teaching with great care. Faculty need to take into account the complexity of the field, the recursivity of the meaningful learning process, and also consider the unique knowledge and learning strategy of each individual student. Furthermore, the role of the courses like biomechanics, independent of the knowledge field they represent, is also to lead students, with the guidance of a teacher, to construct relevant, applied, or professional knowledge. This goal is directly dependent on the interaction of undergraduate courses in the field of kinesiology/exercise science, which is essential to enable students to deal in diverse ways with the same knowledge along the various subjects that compose the curriculum of their major (LEMOS, 2011) and future professional practice. Thus, individual courses from this standpoint can help to facilitate the occurrence of learning how to learn meaningfully, taking into account students, teachers, context, and evaluation. As we are dealing here with college level students, it is also the role of courses to come up with situations that enable future professionals to perceive the deficiency of mere memorization, especially when it comes to their own everyday learning and future plans for professional development.

Based on meaningful learning theory principles, professors of introductory biomechanics courses should consider the students' prior knowledge and main points of difficulty from content that will be taught to elaborate the teaching plan to introductory biomechanics course (BELMONT; KNUDSON; LEMOS, 2014). A good teaching strategy would be to show to a novel movement problem commonly faced by physical education professionals that would be difficult to solve through memorized definitions. Tests and activities should be planned to lead the students to think about the relationships between concepts related to the movement problem. Instructors should also plan different activities that explore the same knowledge in different ways to help the students to 
consolidate student learning. In this context learners can think about and with anatomical and biomechanical knowledge, and are more likely to apply this knowledge to solve other movement problems. Real-world problems and inquiry-based activities are examples of strategies that can motivate students to link the concepts and build the knowledge with personal meaning.

The study was limited to the achievement and learning activities of a small sample of Brazilian physical education majors. While small, this study may be the first documenting the hypothesized association between learning biomechanical content and anatomical prerequisite knowledge. Just asking students about difficulties in learning is not enough to understand their problems in making meaningful relationships among concepts and use of these in novel situations. It is important for faculty to know the nature of the problem so that they can help the students to overcome their difficulties. Qualitative research methods allow the examination of individual responses to instruction, and this studies results were consistent with the common opinions of biomechanics faculties that poor mastery of anatomical concepts may interfere with learning biomechanical concepts. More researches are needed to confirm these initial results and to document the variety of student responses to meaningful learning instructional strategies.

\section{CONCLUSION}

The present study used a qualitative case study approach to show that a sample of undergraduate biomechanics students had weak mastery of functional anatomical concepts and a memorization approach to learning that may interfere meaningful learning of biomechanical concepts. Analysis of student interactions and a test data indicated that knowledge of functional anatomy was insufficient, fragmented, or missing. Furthermore, learning by memorization was a commonly used study strategy among these students which may also have contributed to the poor meaningful learning of biomechanical concepts.

\section{ACKNOWLEDGEMENTS}

To Brazilian Federal Agency, CAPES, that provided financial support for this research. 


\section{REFERENCES}

AUSUBEL, D. P. The acquisition and retention of knowledge: a cognitive view. Boston: Kluwer Academic Publishers, 2000.

AUSUBEL, D. P.; NOVAK, J. D.; HANESIAN, H. Educational psychology: a cognitive view. 2th ed. New York: Holt, Rinehart and Winston, 1978.

BARDIN, L. Análise de Conteúdo [Content Analysis]. 4th ed. Lisboa, Portugal: Edições 70, 2009.

BARLOW, D. A. (1997). Interactive approaches to the study to the dynamics of human anatomy. 1997. In: National Symposium on Teaching Biomechanics, 4., 1997, Denton. Proceedings... Denton, TX: Texas Woman's University, 1997, p. 13-20.

BELMONT, R. S. A evolução da aprendizagem significativa da biomecânica em um contexto de formação inicial de professores de educação física [Unfolding/advancement of meaningful learning in biomechanics in the initial stages of the development of physical education teachers]. Rio de Janeiro, 2010. 200f. Dissertation (Master in Bioscience and Health Teaching) - Oswaldo Cruz Foundation, Rio de Janeiro, 2010.

BELMONT, R. S.; KNUDSON, D.; LEMOS, E. S. Continuing Education in Biomechanics for Physical Education Teachers. International Journal of New Trends in Arts, Sports \& Science Education, v. 3, n. 1, p. 14-21, 2014.

BERGMAN, E. M.; BRUIN, A. B. H.; HERRLER, A.; VERHEIJEN, I. W. H.; SCHERPBIER, A. J. J. A. Students' perceptions of anatomy across the undergraduate problem-based learning medical curriculum: a phenomenographical study. BMC Medical education, v. 13, p. 152, 2013.

BRETON, H.; HERNANDEZ, J.; BELLO, F.; STRUTTON, P.; PURKAYASTHA, S.; FIRTH, T.; DARZI, A.; VAN DER VLEUTEN, C. P. M. Using multimedia and Web3D to enhance anatomy teaching. Computers \& Education, v, 49, n. 1, p. 32-53, 2007.

GARCEAU, L., KNUDSON, D.; EBBEN, W. Fourth North American survey of undergraduate biomechanics instruction in kinesiology/exercise science. In: International Conference on Biomechanics in Sports, 29., 2011, Porto. Proceedings... Porto, Portugal: Portuguese Journal of Sport Science, 2011, v. 11 (Suppl. 2), p. 951-954.

GINNS, P.; FRASER, J. Personalization enhances learning anatomy terms. Medical Teacher, v. 32, n. 9, p.776778, 2010.

HATZE, H. Letter: The meaning of the term 'Biomechanics'. Journal of Biomechanics, v. 7, n. 2, p. 189-190, 1974.

KALMEY, J.; KULESZA, R. Medical school success strategies: proactive intervention examination. Medical Education, v.47, n. 1, p. 1119, 2013.

KNUDSON, D. Biomechanics concept inventory. Perceptual and Motor Skills, v. 103, n. 1, p. 81-82, 2006.

KNUDSON, D. Fundamentals of biomechanics. 2th ed. New York: Springer, 2007.

KNUDSON, D.; NOFFAL, G.; BAUER, J.; MCGINNIS, P.; BIRD, M.; CHOW, J.; BAHAMONDE, R.; BLACKWELL, J.; STROHMEYER, S.; ABENDROTH-SMITH, J. Development and evaluation of a biomechanics concept inventory. Sports Biomechanics, v. 2, n. 2, p. 267-277, 2003.

LEMOS, E. S. A aprendizagem significativa: estratégias facilitadoras e avaliação [Meaningful learning: facilitative strategies and evaluation]. Meaningful Learning Review, v. 1, n. 1, p. 25-35, 2011. 
LEMOS, E. S. (Re)situando a teoria de aprendizagem significativa na prática docente, na formação de professores e nas investigações educativas em ciências [(Re)situating the meaningful learning theory in the teaching practice, in teacher preparation, and in research studies in science education]. Revista Brasileira de Pesquisa em Educação em Ciências, v. 5, n. 3, p. 38-51, 2005.

LÜDKE, M.; ANDRÉ, M. E. D. A. Pesquisa em educação: abordagens qualitativas [Educational research: qualitative aproaches]. 4th ed. São Paulo: EPU, 2013.

MILLER, S. A.; PERROTTI, W.; SILVERTHORN, D. U.; DALLEY, A. F.; RAREY, K. E. From college to clinic: reasoning over memorization is key for understanding anatomy. The Anatomical Record, v. 269, n. 2, p. 69-80, 2002.

MITCHELL, B. S.; MCCRORIE, P.; SEDGWICK, P. Student attitudes towards anatomy teaching and learning in a multiprofessional context. Medical Education, v. 38, n.7, p. 737-748, 2004.

NAGAR, S. K.; MALUKAR, O.; KUBAVAT, D.; PRAJAPATI, V.; GANATRA, D.; RATHWA, A. Students' perception on anatomy teaching methodologies. National Journal of Medical Research, v. 2, n.1, p. 111-112, 2012.

PANDEY, P.; ZIMITAT, C. Medical students' learning of anatomy: memorization, understanding and visualization. Medical Education, v. 41, n. 1, p. 7-14, 2007.

POKHREL, R.; BHATNAGAR, R. Audiovisual use in anatomy laboratory facilitates learning. Medical Education, v. 47, n. 11, p. 1119-1120, 2013.

REZENDE, F.; GARCIA, M. A. C.; COLA, C. S. Desenvolvimento e avaliação de um sistema hipermídia que integra conceitos básicos de Mecânica, Biomecânica e Anatomia Humana [Development and evaluation of a hypermedia system that integrates basic concepts of mechanics, biomechanics and human anatomy]. Investigações em Ensino de Ciências, v. 11, n. 2, p. 239-259, 2006.

SMITH, C. F.; MATHIAS, H. S. Medical students' approaches to learning anatomy: students' experiences and relations to the learning environment. Clinical Anatomy, v.23, n. 1, p. 106-114, 2010.

TERRELL, M. Anatomy of learning: instructional design principles for the anatomical sciences. The Anatomical Record, v. 289, n. 6, p. 252-260, 2006. 